\title{
Changes in the Relative Abundance of miR-205, miR-26a-5p, let-7b and their Target Genes in Vitrified Bovine Embryos after Phenazine Ethosulfate Supplementation
}

\author{
Yasser H.A. Saber ${ }^{1}$, Sally Ibrahim ${ }^{1}$, Karima Gh. M. Mahmoud ${ }^{1}$, Wahid M. Ahmed ${ }^{1}$, RefaAt \\ S.A. RAGAB ${ }^{2}$, Adel A.M. SEIDA ${ }^{2^{*}}$ \\ ${ }^{1}$ Department of Animal Reproduction and A.I, Veterinary Research Division, National Research Centre, Dokki, \\ 12622 Giza, Egypt; ${ }^{2}$ Department of Theriogenology, Faculty of Veterinary Medicine, Cairo University, Giza, Egypt.
}

\begin{abstract}
Accumulation of lipid droplets is a main obstacle for cryopreservation and low survivability of embryos. This investigation aimed to study the effect of phenazine ethosulfate (PES) supplementation in culture media on the selected miRNAs (miR-205, miR-26a-5p, and let-7b) and their target genes (OCT4, DNMT, CASP3, ATF6, ATP5ME, and ELOVL5), during bovine embryo production. Therefore, a group of two-day bovine embryos was cultured in a medium with lipid-reducing agent, PES $(0.3 \mathrm{mM})$. Another group of embryos without PES was served as a control. Embryos were vitrified and morphologically examined after warming. The viability also was evaluated by culturing for $24 \mathrm{~h}$. After evaluation, embryos were classified into a good or a poor. Afterwards, embryos (blastocyst and morula) were kept at $-80^{\circ} \mathrm{C}$ for RNA extraction and qRT-PCR of the selected miRNAs and their targets. Results revealed that the rate of morula was higher $(P<0.01)$ in treated compared to control groups. After vitrifications, the percentage of good quality embryos increased in treated groups than control groups. Additionally, the rate of dead embryos was higher in control groups. The Let- $7 b$ and miR-205 were significantly over-expressed in the treated good as well as poor embryos compared to control (untreated) good and poor embryos, respectively. However, miR-26 was suppressed in the treated good and poor embryos compared to control (untreated) embryos, respectively. Both of OCT4 and DNMT1 transcripts up-regulated in the treated (good and poor) embryos compared to control groups. The ELOVL5 gene decreased in the treated (good and poor) embryos, compared to control ones. In conclusion, PES supplementation reduced lipid droplets, and improved cryotolerance of the blastocysts via modulation the expression pattern of miRNAs and their target genes.
\end{abstract}

Keywords $\mid$ miRNA, Bovine, Phenazine ethosulfate, Vitrifications, Embryos quality

Received | July 01, 2021; Accepted | August 16, 2021; Published | November 01, 2021

*Correspondence | Karima Gh. M. Mahmoud, Adel AM. Seida, Department of Animal Reproduction and A.I, Veterinary Research Division, National Research Centre, Dokki, 12622 Giza, Egypt; Department of Theriogenology, Faculty of Veterinary Medicine,Cairo University, Giza, Egypt; Email: karimamahmoud@ yahoo.com; adel.seida_55@yahoo.com

Citation | Saber YHA, Ibrahim S, Mahmoud KGM, Ahmed WM, Ragab RSA, Seida AAM (2021). Changes in the relative abundance of miR-205, miR-26a-5p, let-7b and their target genes in vitrified bovine embryos after phenazineethosulfate supplementation. Adv. Anim. Vet. Sci. 9(12): $2157-2167$.

DOI | http://dx.doi.org/10.17582/journal.aavs/2021/9.12.2157.2167

ISSN (Online) | 2307-8316; ISSN (Print) | 2309-3331

Copyright (C) 2021 Saber et al. This is an open access article distributed under the Creative Commons Attribution License, which permits unrestricted use, distribution, and reproduction in any medium, provided the original work is properly cited.

\section{INTRODUCTION}

$\mathrm{M}$ any genetic companies that are concerned with artificial insemination field have started operating in embryo market, which has resulted in an increasing demand in in-vitro (IVP) embryos. This strategy resulted in a profound change in global cattle genetic market (Marsico et al., 2019). Although the great efforts have been done by researchers to improve IVP during the last years, the efficiency remains low (Sudano et al., 2019). The IVP embryos are less resistant to cryopreservation and revealed lower survivability compared with in vivo produced, because of increased lipid droplets (Sanches et al., 2017).

During embryonic development, the required energy is different from stage to another (Thompson, 2000). At 
the very early stage of embryonic development, embryos rely on oxidative phosphorylation to synthesize adenosine triphosphate since their metabolism is poor (Nelson and Cox, 2011). Then, the metabolism becomes higher and embryos use glycolysis process as well as amino acids for blastocele formation (Lima and Souza, 2009). In spite of lipids have a beneficial and a vital role in early embryonic development through providing energy. Their accumulations in the embryonic cytoplasm are reduced embryonic survivability following cryopreservation (Dias et al., 2017). Many studies were done to overcome IVP embryos' low cryopreservation resistance using phenazine ethosulfate (PES) as delipidating chemicals agents (Barceló-Fimbres and Seidel, 2007; Sudano et al., 2011; Ghanem et al., 2014). These chemical agents reduce the fatty acids absorption and synthesis by cells (Batista et al., 2014; Dias et al., 2017).

It was found that PES inhibits fatty acids synthesis by NADH oxidation to NADP, which subsequently promotes the energy metabolism balance, as well as pentose phosphate pathway (PPP) reactions (Sudano et al., 2011; Ghanem et al., 2014). It was indicated that addition of 0.3 $\mu \mathrm{M}$ PES during in vitro culture (IVC) of bovine embryos accelerated glucose metabolism and reduced the amount of large lipid droplets in cytoplasm (De La Torre-sanchez et al., 2006). Furthermore, culture of bovine embryos with PES revealed obvious improvements in embryonic cryotolerance and survival rate after cryopreservation (Barceló-Fimbres and Seidel, 2007).

No doubt that the morphological assessment that used for evaluation embryo quality is not sufficient for the accurate judgment of embryonic viability. So, the precise assessment and selection of good quality embryos could be achieved by molecular investigation of certain markers that are relevant to each stage of embryonic development (Spricigo et al., 2014; Leme et al., 2016). Additionally, analysis of genes related to lipid metabolism is very important in order to understand the embryonic response to different treatments, which used to reduce lipid droplets in embryonic cytoplasm and improve cryotolerance as well as survivability (Baldoceda et al., 2015).

MicroRNAs (miRNAs) is a tiny non-coding RNAs; around 19-22 nucleotides in length (Ling et al., 2013). This small non-coding RNAs is one of key-player at posttranscriptional level, and express in oocytes, testis, granulosa cells, and embryos (Lin et al., 2019). It was found that miRNAs regulate many genes in stage specific manner, during different stages of embryonic developmental (Kropp and Khatib, 2015; Salilew-Wondim et al., 2020).Also, it was shown that embryos are well equipped with a huge amount of maternal miRNAs that inherited by embryos until activation of early embryonic genome (Tesfaye et al., 2018).
It was indicated that the octamer-binding transcription factor4 (OCT4) is one of the master regulators for pluripotency during early stages of embryonic development (Sadeesh et al., 2016). Besides, DNA methyltransferase (DNMT) plays an important function during oocytes maturation and early stages of embryonic development (Lodde et al., 2009). Michalak and Gye (2015) reported that activating transcription factor 6 (ATF6) is one of coping gene, which induced in preimplantation embryos as a normal part of the cellular adaptive mechanism to endoplasmic reticulum (ER) stress. Apoptosis-related cysteine peptidase (CASP3) has a critical role in the process of early apoptosis, and their up-regulation reflects early apoptosis (Wei et al., 2017). Genes such as: ATP5F1E (ATP synthase peripheral stalk-membrane subunit B) and ATP5ME (ATP synthase membrane subunit E) play important roles in the mitochondrial respiration, energy transport, and ATP synthesis during embryonic development (El-Sheikh et al., 2019). At early bovine embryo development, lipid fluctuation was observed with increase in ELOVL5 (ELOVL fatty acid elongase 5) expression, whereas ELOVL5 is responsible for fatty acids elongation at the morula stage (Sudano et al., 2016).

Despite the beneficial influences of PES on embryo quality that produced in vitro. The effect of PES was investigated only at the transcription level mainly for genes that regulate lipid metabolism and mitochondrial function. So far, the impact of PES on microRNA that fine-tune genes associated with lipid metabolism, mitochondrial function and viability as well as pluripotency genes was not study in bovine embryos. Therefore, the current study was aimed to investigate the effect of PES supplementation in culture media on the selected miRNAs (miR-205, miR-26a-5p, and let-7b) and their target genes (OCT4,DNMT, CASP3, ATF6, ATP5ME, and ELOVL5), during bovine embryo production. These candidates are relevant to pluripotency, cell programming, postcryopreservation viability, embryonic quality, lipid metabolism, and mitochondrial activity.

\section{MATERIALS AND METHODS}

\section{Cumulus-OOCYTE COMPleXes (COCs) COLLECTION, SELECTION AND MATURATION IN VITRO}

Mature Egyptian cow ovaries were collected from Benisuef slaughter house in sterile modified Dulbecco's phosphate saline (D-PBS; $\mathrm{pH}=7.2$ ) containing100 $\mu \mathrm{g} /$ $\mathrm{mL}$ streptomycin and $100 \mathrm{IU} / \mathrm{mL}$ penicillin at $37^{\circ} \mathrm{C}$. They were rinsed in D-PBS then in normal saline. Oocytes were harvested from follicles $(3-7 \mathrm{~mm})$ using 18-gauge needle tied to a disposable $10-\mathrm{ml}$ syringe within $3-5 \mathrm{~h}$ after slaughtering. Evenly granulated oocytes surrounded with homogeneous cytoplasm and at least two layers of compact 
cumulus cells were chosen for maturation. COCs were washed in D-PBS, then in in- vitro maturation medium (IVM) that contained TCM-199 (Gibco) supplemented with $10 \%$ calf serum (Gibco) and $50 \mu \mathrm{g} / \mathrm{mL}$ gentamycin (G-1272 Sigma). The COCs were cultured in groups of $10-20 / 100 \mu \mathrm{L}$ drop of IVM medium in Petri-dishes (Nunclone, Roskilde, Denmark) with mineral oil (M4810 , Sigma) overlay for $22 \mathrm{~h}$ at $38.5^{\circ} \mathrm{C}, 5 \% \mathrm{CO}_{2}$ and $95 \%$ humidity.

\section{IN VITRO EMBRYO PRODUCTION}

Spermatozoa were treated according to Niwa and Ohgoda (1988). Frozen straws were thawed at $35-37^{\circ} \mathrm{C}$ for $30 \mathrm{sec}$ in a water bath. Sperms were washed in BO medium (Brackett and Oliphant, 1975), containing10 $\mu \mathrm{g} /$ $\mathrm{mL}$ heparin and $2.5 \mathrm{mM}$ caffeine without BSA (Sigma, St. Louis, MO) by centrifugation at $800 \times \mathrm{g}$ for $10 \mathrm{~min}$. To optimize the spermatozoa concentration to $12.5 \times 10^{6}$ sperm, the sperm pellets were diluted with $\mathrm{BO}$ containing $20 \mathrm{mg} / \mathrm{mL}$ bovine serum albumin. Oocytes were washed before introducing to the sperm in BO medium with 10 $\mathrm{mg} / \mathrm{mL} \mathrm{BSA}$, then added to $100 \mu \mathrm{L}$ droplets of diluted sperm (about 5-10 oocytes/droplet). The oocytes and spermatozoa were co-cultured at $5 \% \mathrm{CO}_{2}, 95 \%$ humidity, and $38.5^{\circ} \mathrm{C}$ for $5 \mathrm{~h}$. The oocytes were then washed several times in TCM-199 to remove the associated spermatozoa. Two-day embryos were then cultured in a medium with Lipid-reducing chemical, phenazineethosulfate (PES). The most appropriate concentrations of PES $(0.3 \mathrm{mM})$ were selected by Barceló-Fimbres and Seidel (2007) for bovine embryo culture that consisting of TCM-199, 50 $\mu \mathrm{g} / \mathrm{mL}$ gentamycin and $10 \%$ serum. A group of embryos without PES was left as a control. After $72 \mathrm{~h}$ of culture, cleavage was determined, and embryos were counted on day 7 (E1-Naby et al., 2016).

\section{VITRIFICATION AND WARMING OF EMBRYOS}

In TCM 199 supplemented 20\% fetal calf serum, the vitrification solutions were produced. Embryos were vitrified in $1.75 \mathrm{M} \mathrm{EG}+1.75 \mathrm{M}$ DMSO for $2.5 \mathrm{~min}$ (step one), and then in 3.5 M EG + 3.5 M DMSO for $45 \mathrm{sec}$ (second step) in $0.25 \mathrm{~mL}$ straws. Immediately, straws were cooled in liquid nitrogen vapor for $1 \mathrm{~min}$ before storing in liquid nitrogen for 30 days. Straws were warmed by holding for $10 \mathrm{sec}$ in air, $30 \mathrm{sec}$ in water at $37^{\circ} \mathrm{C}$, and flicked four to six times to mix columns. Then, embryos were washed in $0.5 \mathrm{M}$ galactose for $5 \mathrm{~min}$ at room temperature. In the end, the embryos were flushed five times in TCM plus $5 \% \mathrm{FCS}$ and cultured at $38.5^{\circ} \mathrm{C}, 5 \% \mathrm{CO}_{2}$ for further $24 \mathrm{~h}$ (Mahmoud et al., 2015).

\section{Survival ASSAY}

Embryos were morphologically examined after warming and the viability was evaluated by culturing for $24 \mathrm{~h}$. The embryos developed to advanced stages, were considered to be survived. The morulae that developed into more advanced stage (blastocysts) and the blastocysts that reexpanded were considered as surviving (Mahmoud et al., 2015). After evaluation, embryos were classified into a good or a poor. The embryos (blastocyst and morula) were transferred to a small Eppendorf tube and stored at $-80^{\circ} \mathrm{C}$ for RNA extraction.

\section{IN-SILICO ANALYSIS FOR THE IDENTIFIED CANDIDATE} MIRNAS

The differentially expressed genes in bovine embryos were uploaded into miRNA prediction tools such as: DIANA-microT v3.0 (http://diana.cslab.ece.ntua.gr/ microT/), miRecords (http://mirecords.biolead.org/), and miRWalk (http://mirwalk.umm.uni-heidelberg. de/). Then the miRNAs hits were filtered based on their probable relevance for pluripotency, cell-programming, post cryopreservation viability, embryonic quality, lipid metabolism, and mitochondrial activity at least in four different search algorithms. Results showed that bta-let$7 b$, bta-miR-26 and bta-miR-205, as potential targets. Interestingly, bta-let-7b, bta-miR-26 and bta-miR-205 were mentioned by Kropp and Khatib (2015); Tesfaye et al. (2018); Salilew-Wondim et al. (2020), who revealed that these miRNAs were targeting lipid metabolism, as well as mitochondrial activity genes.

RNA ISOLATION, CDNA SYNTHESIS (FOR LARGE AND SMall RNA), AND QUantitative REAL-Time PCR (QRT-PCR)

Total RNA was extracted from control and PES treated embryos; five independent biological replicates (10 pooled blastocysts/each) using miRNeasy mini kit (Qiagen, Hilden, Germany). The isolated total RNA was done according to the manufacturer's protocol. To exclude any potential genomic DNA contamination, the extracted RNA was treated to on-column DNA digestion with the RNase-free DNase kit (Qiagen, Hilden, Germany), and then stored at $80^{\circ} \mathrm{C}$. The total RNA concentration was measured using a Nano Drop 2000/c spectrophotometer (Thermo Fisher Scientific, Wilmington, USA). Furthermore, the integrity of RNA was assessed using 1.5\% agarose electrophoresis stained with ethidium bromide. One $\mu \mathrm{g}$ RNA was reverse transcribed into cDNA (for large RNA), using the Revert Aid First Strand cDNA Synthesis Kit (Thermo Fisher scientific, USA), and then the mixture was then run in a thermocycler (Bio-Rad, USA) programmed for $42^{\circ} \mathrm{C}$ for $60 \mathrm{~min}, 70^{\circ} \mathrm{C}$ for $5 \mathrm{~min}$, hold at $4^{\circ} \mathrm{C}$. The $\mathrm{cDNA}$ was kept at $-20^{\circ} \mathrm{C}$. The specific primer for each transcript was constructed using Primer3 program version 4.0 (http:// primer3.ut.ee/), according to Rozen and Skaletsky (2000), and specifics of primers are shown in Table 1. Quantitative real-time PCR of mRNAs was done in StratageneMx 
OPEN OACCESS

3000P instrument (Agilent Technologies, USA), using a Maxima SYBR Green/ROX qPCR Master Mix (2×), (Thermo Fisher scientific, USA) and the following conditions: $95^{\circ} \mathrm{C}$ for $10 \mathrm{~min}, 40$ cycles at $95^{\circ} \mathrm{C}$ for $15 \mathrm{sec}$, $60^{\circ} \mathrm{C}$ for $30 \mathrm{sec}$ and $72^{\circ} \mathrm{C}$ for $30 \mathrm{sec}$. At the end of the run, the melting curve was examined to determine the specificity of the amplification. The comparative threshold cycle $(\Delta \Delta \mathrm{Ct})$ method was used to evaluate the data and normalization was done using the geometric means of two housekeeping genes GAPDH, $\beta$-actin (ACTB). Around $10 \mathrm{ng}$ of total RNA was reverse transcribed via Multi Scribe reverse transcriptase (for small RNA). The RT primers were added separately for each miRNA (let-7b, miR-26, and miR205) according to the supplier's instructions. Real-time PCR was done in a volume of $10 \mu \mathrm{l}$, using $0.7 \mu \mathrm{l}$ of RT product, $0.5 \mu \mathrm{l}$ of particular primers with probes (Table 2), and TaqMan Universal PCR Master Mix II (Thermo Fisher Scientific, Wilmington, USA). Amplification was carried out using a StratageneMx 3000P instrument (Agilent Technologies, USA) with initial denaturation for $10 \mathrm{~min}$ at $95^{\circ} \mathrm{C}$, followed by 40 cycles of $15 \mathrm{sec}$ at $95^{\circ} \mathrm{C}$ and $60 \mathrm{sec}$ at $60^{\circ} \mathrm{C}$ with. The data were examined by the comparative threshold cycle $(\Delta \mathrm{Ct})$ method and normalization was analyzed using geometric means of $5 \mathrm{~S}$, and U6.

Table 1: The primers used for qRT-PCR analysis.

\begin{tabular}{|c|c|c|c|c|}
\hline Gene & Sequence $5^{\prime}$ to $3^{\prime}$ & Accession no & Product size (bp) & Annealing ${ }^{\circ} \mathrm{C}$ \\
\hline CASP3 & $\begin{array}{l}\text { F: ACTGTGGTATTGAGACAGACA } \\
\text { R: CGTACTTTTTCAGCATCTCAC }\end{array}$ & XM_006075118.1 & 175 & 50 \\
\hline OCT4 & $\begin{array}{l}\text { F: CAGAAGAGGATCACACTAGGAT } \\
\text { R: GTCTCTGCCTTG CAT ATCTC }\end{array}$ & NM_174580.3 & 212 & 53 \\
\hline ACTB & $\begin{array}{l}\text { F: GGCATTCACGAAACTACCTT } \\
\text { R: CAATCCACACGGAGTACTTG }\end{array}$ & NM_001290932.1 & 198 & 55 \\
\hline GAPDH & $\begin{array}{l}\text { F: CTACATGGTCTACATGTTCCAG } \\
\text { R: CCTTCTCCATGGTAGTGAAGA }\end{array}$ & XM_006065800.1 & 200 & 50 \\
\hline DNMT & $\begin{array}{l}\text { F: AGAGTAAGACCAGGAACACAC } \\
\text { R: CTAGCTAGATCTTTGGGTTGAC }\end{array}$ & XM_015471993.1 & 213 & 55 \\
\hline ATP5ME & $\begin{array}{l}\text { F:CGCCAAGCGCTACAATTA } \\
\text { R:GAAGGGCAGGCTCACTTCAATA }\end{array}$ & NM_176639.2 & 150 & 54 \\
\hline ELOVL5 & $\begin{array}{l}\text { F:ATGCTCAACATCTGGTGGTTC } \\
\text { R:GGATGATGGTCAGCACAAACT }\end{array}$ & NM_001046597.1 & 199 & 55 \\
\hline ATF6 & $\begin{array}{l}\text { F:AAGACAAGCCCATCATTGGT } \\
\text { R:TGATTGTTTTTGCTGGAACG }\end{array}$ & XM_024989877.1 & 162 & 51 \\
\hline
\end{tabular}

Table 2: List of miRNAs names, miRbase accession numbers and their mature sequences.

$\begin{array}{lll}\text { miR name } & \text { Accession number } & \text { Mature miRNA sequence } \\ \text { bta-let7-b } & \text { MIMAT0004331 } & \text { UGAGGUAGUAGGUUGUGUGGUU } \\ \text { bta-miR-205 } & \text { MIMAT0003545 } & \text { UCCUUCAUUCCACCGGAGUCUG } \\ \text { bta-miR-26 } & \text { MIMAT0003516 } & \text { UUCAAGUAAUCCAGGAUAGGCU }\end{array}$

\section{STATISTiCAl AnAlysis}

Eight replicates in embryo development data and four replicates in vitrified embryos in both treated and control groups were statistically analyzed by ANOVA using statistical software SPSS version 16.0. The LSD test was used to compare the means. At $P<0.05$ level, differences were considered significant.

The Norm Finder has been used to select the most stable reference gene for mRNA and the miRNAs expression profile (Andersen et al., 2004). All data were tested for homogeneity using Gaussian distribution; the expression of selected genes as well as miRNAs was analyzed using unpaired $t$ test with Welch's correction (Graph Pad Software, Inc., San Diego, CA, USA). The data is graphed as the mean \pm standard error of the mean (S.E.M), with $P$ values $<0.05$ were considered statistically significant. GraphPad Prism 9.0 was employed for performing statistical analysis and generating bar graphs.

\section{RESULTS}

Table 3 shows that there was no significant difference in percentage of the cleavage and blastocyst between PES $(0.30 \mu \mathrm{M})$ and control group. However, the rate of morula was significantly greater in treated $(P<0.01)$ compared to control group.

With respect to the vitrified embryos evaluated directly after warming (Table 4), the percentage of good quality 
embryos was significantly $(P<0.05)$ higher in treated than control groups, while the rate of dead embryos were significantly $(P<0.01)$ higher in control than treated groups. The percentages of morphologically poor quality embryos did not differ significantly between the two groups.

Morphologically normal vitrified embryos were evaluated also after $24 \mathrm{~h}$ of culture (Table 4 ), the rate of good viable embryos was significantly $(P<0.01)$ greater in treated than control groups. The rate of poor and dead embryos did not differ significantly between the two groups.

EXPRESSION PROFILING OF PLURIPOTENCY, CELLPROGRAMMING, EMBRYO QUALITY ASSOCIATED GENES The OCT4 mRNA was shown an increase $(P<0.001)$ in the treated good embryo compared to control (untreated) groups. Also, OCT4 transcript was up-regulated $(P<0.001)$ in the treated poor embryo compared to control (untreated) groups. The DNMT1 gene increased $(P<0.001)$ in the treated good embryo compared to control (untreated) groups. Also, DNMT1 transcript was up-regulated $(P<0.05)$ in the treated poor embryo compared with control (untreated) groups. The CASP3 mRNA was not shown any significant changes in the treated good embryo, in comparison with control untreated groups. While, there was an increase $(P<0.05)$ in the relative expression of CASP3 gene in treated poor embryo compared to control groups (Figure 1).

RELATIVE ABUNDANCE OF LIPID METABOLISM, MITOCHONDRIAL ACTIVITY, AND ENDOPLASMIC RETICULUM STRESS ASSOCIATED GENES IN BOVINE EMBRYOS

The ATP5ME gene was down-regulated $(P<0.05)$ in the treated good embryo in comparison with control untreated groups. No significant changes were noticed in the relative abundance of ATP5ME transcript between the treated poor embryo and control untreated groups. The ELOVL5 mRNA decreased $(P<0.01)$ in the treated good as well as poor embryos, compared to control untreated good and poor embryos, respectively. The ATF6 transcript was not revealed any significant changes among different groups (Figure 2).
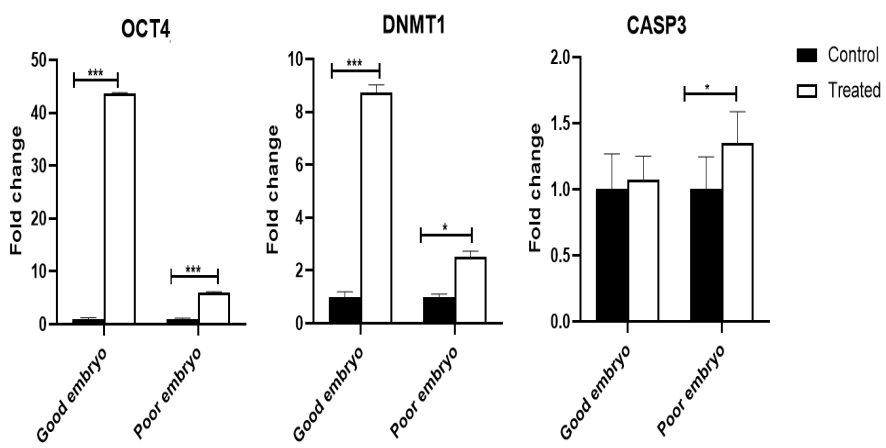

Figure 1: Expression profiling of pluripotency, cellprogramming, embryo quality associated genes. Stars represent statistical significance level at"; $P<0.05, \cdots, P_{<}$ 0.001
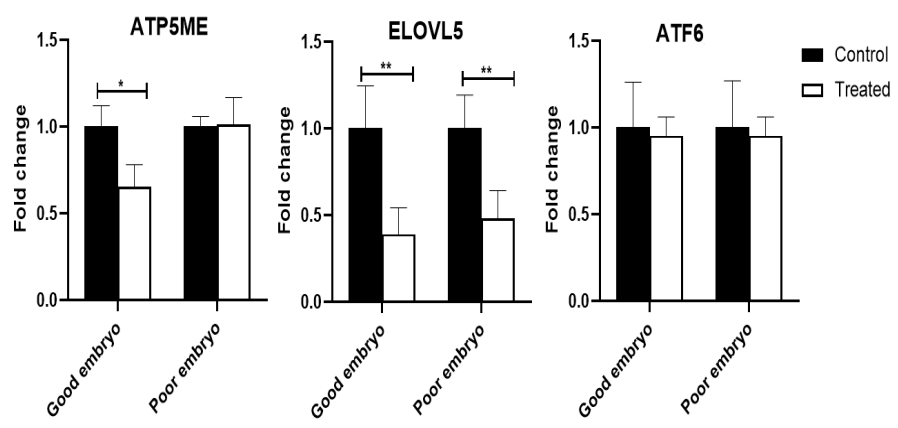

Figure 2: Relative abundance of lipid metabolism, mitochondrial activity, and endoplasmic reticulum stress associated genes in bovine embryos. Stars represent statistical significance level at "; $P<0.05, " ; P<0.01$.

Table 3: Developmental competence of cattle oocytes after culture supplementation with Phenazineethosulphate (Mean $\pm \mathrm{SE})$.

\begin{tabular}{|lllll|}
\hline Blastocyst no (\%) & Morulae & Cleavage no (\%) & $\begin{array}{l}\text { Total No. of } \\
\text { inseminated oocytes }\end{array}$ & parameter \\
\hline $198(18.78 \pm 7.4)$ & $432(35.7 \pm 1.9)$ & $636(65.7 \pm 2.8)$ & 936 & Control \\
\hline $204(23.5 \pm 3.3)$ & $504\left(44.8 \pm 2.1^{*}\right)$ & $882(70.2 \pm 1.9)$ & 1392 & $0.30 \mu \mathrm{MPES}$ \\
\hline
\end{tabular}

Percent from total inseminated oocytes. No.= number; $\mathrm{t}$-test ( $P<0.01,8$ replicates).

Table 4: Cryotolerance of cattle embryos after culture supplementation with Phenazineethosulphate (Mean $\pm \mathrm{SE}$ ).

\begin{tabular}{|c|c|c|c|c|c|c|c|}
\hline \multicolumn{6}{|c|}{ Morphologically normal embryos } & \multirow{3}{*}{$\begin{array}{l}\text { No. of vitri- } \\
\text { fied-warmed } \\
\text { embryos }\end{array}$} & \multirow[t]{3}{*}{ Parameter } \\
\hline \multicolumn{3}{|c|}{$24 \mathrm{~h}$ after warming No (\%) } & \multicolumn{3}{|c|}{ Directly after warming No (\%) } & & \\
\hline Dead & Poor & Good & Dead & Poor & Good & & \\
\hline $70(31.1 \pm 5.7)$ & $35(19.5 \pm 3.6)$ & $101(49.3 \pm 4.9)$ & $14\left(7.1 \pm 0.8^{* *}\right)$ & $70(31.0 \pm 5.2)$ & $122(61.9 \pm 5.1)$ & 206 & Control \\
\hline $52(19.8 \pm 1.6)$ & $44(17.5 \pm 1.2)$ & $166\left(62.7 \pm 1.8^{*}\right)$ & $6(1.5 \pm 0.9)$ & $54(19.9 \pm 2.5)$ & $202\left(78.5 \pm 2.6^{*}\right)$ & 262 & $\operatorname{PES}(0.30 \mu \mathrm{M})$ \\
\hline
\end{tabular}

t - test $\left(" P<0.05-"{ }^{*} P<0.01,4\right.$ replicates $)$. 
THE EXPRESSION PATTERN OF MIRNAS (LET-7 $B$, MIR26, AND MiR-205), WHICH ARE TARGETING CASP3, DNMT1, AND ELOVL5 IN BOVINE EMBRYOS

The Let-7b was over-expressed $(P<0.001)$ in the treated good as well as poor embryos compared to control (untreated) good and poor embryos, respectively. The miR-26 was suppressed in the treated good $(P<0.001)$ as well as poor $(P<0.01)$ embryos compared to control (untreated) good and poor embryos, respectively. The miR205 increased in the treated good $(P<0.001)$ as well as poor $(P<0.01)$ embryos compared to control (untreated) good and poor embryos, respectively (Figure 3 ).
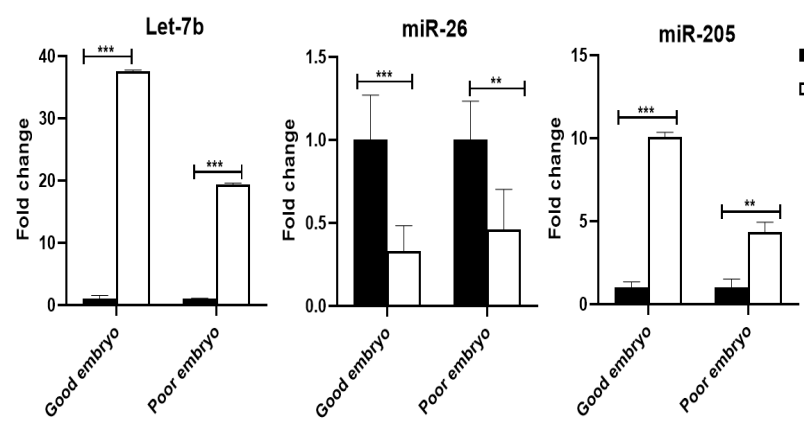

Figure 3: The expression pattern of miRNAs (Let-7b, miR26, and miR-205), which are targeting CASP3, DNMT1, and ELOVL5 in bovine embryos. Stars represent statistical significance level at "; $P<0.01,{ }^{*+20} ; P<0.001$.

\section{DISCUSSION}

Lipid droplets, in oocytes and embryos are considered one of the main factors associated with poor cryosurvival. Within the last decade, different trials have been done to reduce oocytes lipid droplets using mechanical and chemical removal by using delipidating agents (Barrera et al., 2018). The current work aimed to investigate the influence of phenazineethosulfate (PES) supplementation in culture media on the selected miRNAs (miR-205, miR26a-5p, and let-7b) and their target genes (OCT4,DNMT, CASP3, ATF6, ATP5ME, and ELOVL5), during bovine embryo production. Many intrinsic factors are believed to have harmful effects in some mammalian species and from these factors; lipid content of preimplantation embryos. Besides, cytoplasm of developing embryo of cattle and sheep contains high lipids compared to other species (McEvoy et al., 2000). Our data showed that the addition of PES substrate to maturation media significantly enhanced the cleavage rate and viability of cattle embryos. These findings were in agreement with the results showed by many authors (De La Torre-sanchez et al., 2006; BarcelóFimbres and Seidel, 2007; Sudano et al., 2011; Ghanem et al., 2014) who demonstrated that PES had improved embryo quality and their cryotolerance. In support to this notion, the mitochondrial membrane potential of early blastocysts has increased dramatically (Romek et al., 2011) as the oxidation rate of various fatty acids increased (Tsujii et al., 2001). In our study, morula and blastocyst quality improved in the presence of PES compared with the control counterpart. These findings were in agreement with Sudano et al. (2011) who found that embryos cultured with PES had greater hatching rates. Improvements in embryo quality are due to a reduction in the cytoplasmic lipid content, thus reducing the production of free radicals within the embryo lipid peroxidation (Seidel, 2006; Barceló-Fimbres and Seidel, 2007).

MicroRNAs (miRNAs) are important regulators of cellular differentiation and dedifferentiation. They involve in many developmental processes including; embryo development and preimplantation function by balancing pluripotence with differentiation in the embryo and embryo stem cells so understanding miRNAs regulatory mechanisms during embryogenesis could be used as prognostic molecular markers. In contrast, dysregulation of key miRNAs could alter the genes regulating embryonic development (Reza et al., 2019; Salilew-Wondim et al., 2020). To obtain a good as well as viable embryo, expression of several genes involving transcriptional and post-transcriptional (mRNA turnover, processing, storage and translation) must be regulated (Lasko, 2011; Baranyai et al., 2015). Under in vitro conditions, the changes in miRNAs profile are fully related to the environment of in-vitro maturation and/ or materials supplementation (Xiao et al., 2014). Here in the current work, the expression pattern of miRNAs (Let7b, miR-26, and miR-205), which are targeting CASP3, DNMT1, and ELOVL5 in bovine embryos was affected by addition of PES material compared to control groups. Previously, it was found that transfection of miR-26b in breast cells showed declined expression of DNMT3B. Furthermore, transfection of miR-26b antagomiR has demonstrated an over-expression of DNMT3B, indicating that this miRNA is involved in DNMT3b regulation (Sandhu et al., 2012). Many miRNA identified as differentially expressed miRNA regulate genes associated with cellular development (Kropp et al., 2014). Some studies have reported the involvement of miRNAs in embryogenesis and renewing of cells (Mondou et al., 2012). Childs et al. (2009) reported that miRNAs expression levels (miR-205 and let-7d) can be used as prognostic markers of cells survival and recurrence. The miR-26a is abundantly expressed during follicular growth and development in cow ovarian tissues (Salilew-Wondim et al., 2014). Furthermore, miR-205 is an important miRNA linked to adipogenesis and lipid metabolism (Cui et al., 2014). It is considered as an important regulator in controlling hepatic lipid metabolism through its negative effect on hepatic mRNA expression (Tao et al., 2018). The level of miR-205 expression is increased in hepatoma cells during adipogenesis, and it reduced the levels of glycogen 
synthase kinase 3 beta in preadipocyte cells (Yu et al., 2014).

Evaluation of morphology and investigation of genes expression is an essential step during early embryonic development (Lonergan et al., 2003; Cote et al., 2011). In the present study, it was noticed that overexpression of genes related to pluripotency and cell reprogramming in the treated good embryo compared to control (untreated) groups, while the genes related to lipogenesis had been down-regulated. The pattern of DNA methylation is thought to have an important role in gene expression regulation and the expression of imprinted genes, which is important during oocyte maturation and early stages of embryonic development (Lodde et al., 2009). The current findings revealed that addition of lipid metabolism regulator increased DNMT expression. DNMT is necessary for the maintenance of DNA methylation profiles, particularly imprinted gene methylation, throughout the early stages of embryonic reprogramming period to avoid defects in developmental pathway and consequently, onset of adverse health outcomes in offspring (Breton-Larrivee et al., 2019). OCT4 is well known as one of the master regulators of pluripotency and stem cell formation during the early phases of embryonic development (Sadeesh et al., 2016). The present data showed significant overexpression of OCT4 mRNA resulted from addition of PES material. In vitro, OCT4 is necessary for the creation and maintenance of embryonic stem cells as well as the pluripotent reprogramming of somatic cells. However, in vivo, it prevents ectopic trophoblast development in early embryos (Bin et al., 2014). Besides, OCT4 transcript presents in all cells of embryos at the morula stage, it is expressed strictly in inner cell mass (ICM) cells, mediated by the action of gene products expressed on trophectoderm cells (Ralston and Rossant, 2008).

Inhibition of caspase, may prevent cryopreservation induced aberrant apoptosis and increase IVP bovine embryos cryotolerance (Pero et al., 2018). In the present study, the expression profile of CASP3 transcriptin good embryos was not significantly affected in response to lipid modulating. During cryopreservation processes, several variables including mechanical/osmotic injury and oxidative stress change the physical properties of cellular structures, resulting in the activation of the apoptotic pathways and cell death (Paash et al., 2004). A pivotal role of apoptosis in cell cryoinjury has been identified by Stroh et al. (2002), who revealed that cryopreservation promotes the pro-apoptotic activity of caspase 3 in hematopoietic cells. Sudano et al. (2011) found that adding PES to culture media from Day 2.5 to Day 4 decreased lipid content, increased blastocoele re-expansion after vitrification, reduced apoptosis in vitrified blastocysts and improved embryo quality. Our results showed that low expression of genes responsible for lipid formation in response to the addition of lipid scavenger in maturation and culture media. Excessive accumulation of saturated fat is associated with mitochondrial and endoplasmic reticulum damage with induction of oxidative stress (Wu et al., 2011). The evaluation of the expression of genes associated with lipid metabolism has been carried out to predict the ability of embryos to respond to substances, which may generate positive responses to the IVP embryos resistance to the cryopreservation process (Takahashi et al., 2013; Batista et al., 2014; Ghanem et al., 2014; Baldoceda et al., 2015). The ELOVL5 plays an important role in the determination of embryonic lipid droplet content. Blockage of ELOVL5 translation revealed a clear effect on the expression of particular lipids and promoted increased deposition of cytoplasmic lipid droplet (Lanzarini et al., 2021). A previous study concluded that overexpression of ELOVL5 gene at the morula stage preceded an increased abundance of a series of lipids at the blastocyst stage (Sudano et al., 2016). Stress coping mechanisms are essential to reduce or overcome damage caused by environmental changes (Michalak and Gye, 2015). In the current study, there was no change in the expression of gene related to endoplasmic reticulum stress of produced embryos treated with PES. During embryonic development, embryo secretes growth factors that promote embryonic survival during the stage of blastocyst, where cell number increases by the activation of transcription as well as protein synthesis (Abraham et al., 2012). Additionally, ATF6 has a vital role during differentiation and generate a new strategy to form mesodermal tissues (Kroeger et al., 2018). Furthermore, ATF6 is inducible in oocytes and preimplantation embryos, as a normal part of the cellular adaptive mechanism during the developmental stages of preimplantation embryos (Michalak and Gye, 2015). ATF6 loss disrupts the homeostasis of endoplasmic reticulum(ER)and increased ER stress induced damage and cell death (Chiang et al., 2017). ATF6 dysfunction in mammals leads to pathology in many disease models, including obesity associated with ER stress (Jin et al., 2017). Earlier studies indicate that ATF6 plays a vital role in vertebrate embryogenesis and early development (Jang et al., 2012). A clear change in mitochondrial activity of embryos treated with lipid regulators was found and this change was associated to expression of embryo metabolism candidate marker gene (ATP5ME). Takahashi et al. (2013) also reported increasing in the amount of ATP and expression of metabolic-related genes in embryos treated with delipidating agent. Consequently, mechanism of working of PES is to adjust amount of fatty acid by reduction of NADPH to NADP which activates the pathway of pentose phosphate that 
leads to glucose metabolism and ATP production (De La Torre-sanchez et al., 2006; Barceló-Fimbres and Seidel, 2007; Sudano et al., 2011).

\section{CONCLUSIONS AND RECOMMENDATIONS}

To the best of our knowledge, this is the first study showed the alterations in miRNAs (Let-7b, miR-26, and miR205) and their targeting transcripts (CASP3, DNMT1, and ELOVL5) in response to PES addition in embryo culture media. Furthermore, PES at the concentrations of $0.30 \mu \mathrm{M}$ as a supplement in embryo culture medium had dual effects as a metabolic activator and reduced amount of large lipid droplets in cytoplasm to enhance the blastocysts cryotolerance. Further study is required to investigate the precise regulatory role of these candidates miRNA in response to PES addition in embryo culture media.

\section{NOVELTY STATEMENT}

The supplementation of PES in embryo culture medium reduced lipid droplets and enhanced the blastocysts cryotolerance. The effect of PES was investigated at transcription as well as post-transcription levels.

\section{AUTHOR'S CONTRIBUTION}

Yasser H.A. Saber and Sally Ibrahim: conceptualization, methodology, statistics analysis and writing and editing the manuscript. Karima Gh. M. Mahmoud: conceptualization and review the manuscript. Seida A.A. and Ragab: data curation and review the manuscript. Wahid M. Ahmed: statistics analysis and editing the manuscript. All authors have read and agreed to the published version of the manuscript.

\section{INFORMED CONSENT}

Ethical approval was not applicable as ovaries were collected from slaughtered animals for local meat consumption.

\section{CONFLICT OF INTEREST}

The authors have declared no conflict of interest.

\section{REFERENCES}

-Abraham T, Pin CL, Watson AJ (2012). Embryo collection induces transient activation of XBP1 arm of the ER stress response while embryo vitrification does not. Mol. Hum. Reprod., 18: 229-242. https://doi.org/10.1093/molehr/ gar076

-Andersen CL, Jensen JL, Ørntoft TF (2004). Normalization of real-time quantitative reverse transcription PCR data: a model-based variance estimation approach to identify genes suited for normalization, applied to bladder and colon cancer data sets. Cancer Res., 64: 5245-5250. https://doi. org/10.1158/0008-5472.CAN-04-0496

-Baldoceda L, Gagné AD, Ferreira CR, Robert AC (2015). Genetic influence on the reduction in bovine embryo lipid content by L-carnitine. Reprod. Fertil. Dev. Melbourne, 28(8): 1172-1184. https://doi.org/10.1071/RD14215

- Baranyai T, Herczeg K, Onodi Z, Voszka I, Modos K, Marton N, Nagy G, Mager I, Wood MJ, El Andaloussi S, Palinkas Z, Kumar V, Nagy P, Kittel A, Buzas EI, Ferdinandy P, Giricz Z (2015). Isolation of exosomes from blood plasma: qualitative and quantitative comparison of ultracentrifugation and size exclusion chromatography methods. PLoS One, 10: e0145686. https://doi.org/10.1371/journal.pone.0145686

-Barceló-Fimbres M, Seidel JG (2007). Effects of fetal calf serum, phenazineethosulfate and either glucose or fructose during in vitro culture of bovine embryos on embryonic development alter cryopreservation. Mol. Reprod. Dev., 74: 1395-1405. https://doi.org/10.1002/mrd.20699

- Barrera N, Pedro C, dos Santos N, Cuadro F, Bosolasco D, Mulet AP, Crispo M, Menchaca A (2018). Impact of delipidated estrous sheep serum supplementation on in vitro maturation, cryotolerance and endoplasmic reticulum stress gene expression of sheep oocytes. PLoS One: 1-17. https:// doi.org/10.1371/journal.pone.0198742

- Batista RITP, Raposo NRB, Camposjunior PHA, Pereira MM, Camargo LSA, Carvalho BC, Gama MAS, Viana JHM (2014). Trans-10, cis-12 conjugated linoleic acid reduces neutral lipid content and may affect cryotolerance of in vitro produced crossbred bovine embryos.J.Anim. Sci. Biotechnol. Lond., 5(33): 1-8. https://doi.org/10.1186/2049-1891-533

-Bin GCL, Muñoz-Descalzo S, Kurowski A, Leitch H, Lou X, Mansfield W, Etienne-Dumeau C, Grabole N, Mulas C, Niwa H, Hadjantonakis A, Nichols J (2014). Oct4 is required for lineage priming in the developing inner cell mass of the mouse blastocyst. Development, 141: 10011010. https://doi.org/10.1242/dev.096875

-Brackett BG, Oliphant G (1975). Capacitation of rabbit spermatozoa in vitro. Biol. Reprod., 12: 260-274. https:// doi.org/10.1095/biolreprod12.2.260

-Breton-Larrivée M, Elder E, McGraw S (2019). DNA methylation, environmental exposures and early embryo development. Anim. Reprod., 16(3): 465-474. https://doi. org/10.21451/1984-3143-AR2019-0062

- Chiang WC, Chan P, Wissinger B, Vincent A, SkorczykWerner A, Krawczyński MR, Kaufman RJ, Tsang SH, Héon E, Kohl S, Lin JH (2017). Achromatopsia mutations target sequential steps of ATF6 activation. Proc. Natl. Acad. Sci., 114: 400-405. https://doi.org/10.1073/pnas.1606387114

- Childs G, Fazzari M, Kung G, Kawachi N, BrandweinGensler M, McLemore M, Chen Q, Burk RD, Smith RV, Prystowsky MB, Belbin TJ, Schlecht NF (2009). Lowlevel expressions of microRNAs let-7d and miR-205 are prognostic markers of head and neck squamous cell carcinoma. Am. J. Pathol., 174(3): 736-745. https://doi. org/10.2353/ajpath.2009.080731

- Côté I, Vigneault C, Laflamme I, Laquerre J, Fournier E, Gilbert I, Scantland S, Gagne D, Blondin P, Robert C (2011). Comprehensive cross production system assessment of the impact of in vitro microenvironment on the expression of messengers and long noncoding RNAs in the bovine blastocyst. Reproduction, 142: 99-112. https://doi. org/10.1530/REP-10-0477 
- Cui M, Wang Y, Sun BD, Xiao Z, Ye L, Zhang X (2014). MiR205 modulates abnormal lipid metabolism of hepatoma cells via targeting acyl-CoA synthetase long chain family member 1 (ACSL1) mRNA. Biochem. Biophys. Res. Commun., 444(2): 270-275. https://doi.org/10.1016/j. bbrc.2014.01.051

- De La Torre-sanchezJF, Gardner DK, Prieis K, Gibbons J, Seidel Junior GE (2006). Metabolic regulation of in vitro produced bovine embryos. II. Effects of phenazineethosulfate, sodium azide and 2, 4-dinitrophenol during postcompactation development on glucose metabolism and lipid accumulation. Reprod. Fertil. Dev. Melbourne, 18(5): 597-607. https://doi. org/10.1071/RD05064

- Dias LRO, Pivato I, Dode MAN (2017). Change in energy metabolism of in vitro produced embryos: an alternative to make them more cryoresistant? Semina: Ciencias Agrarias Londrina, 38(4): 2237-2254. https://doi.org/10.5433/1679$0359.2017 \mathrm{v} 38 \mathrm{n} 4 \mathrm{p} 2237$

- El-Naby HH, Mahmoud KGhM, Scholkamy TH, Sosa GAM, Abouel-Roos MEA, Ahmed YF (2016). Influence of epidermal growth factor with cysteamine on in vitro buffalo embryo development. Egypt. J. Vet. Sci., 47(1): 27-39. https://doi.org/10.21608/ejvs.2016.1080

-El-Sheikh M, Mesalam A, Mesalam AA, Idrees M, Lim LK, Kong K (2019). Melatonin abrogates the antiDevelopmental effect of the AKT inhibitor SH6 in bovine oocytes and embryos. Int. J. Mol. Sci., 20(2956): 1-22. https://doi.org/10.3390/ijms20122956

- Ghanem N, Ha AN, Fakruzzaman MD, Bang JI, Lee SC, Kong IK (2014). Differential expression of selected candidate genes in bovine embryos produced in vitro and cultured with chemicals modulating lipid metabolism. Theriogenol. Stoneham, 82(2): 1-13. https://doi.org/10.1016/j. theriogenology.2014.03.024

• Jang WG, Kim EJ, Kim DK, Ryoo HM, Lee KB, Kim SH, Choi HS, Koh JT (2012). BMP2 protein regulates osteocalcin expression via Runx2-mediated Atf6 gene transcription. J. Biol. Chem., 287: 905-915. https://doi.org/10.1074/jbc. M111.253187

- Jin JK, Blackwood EA, Azizi KM, Thuerauf DJ, Fahem AG, Hofmann C, Kaufman RJ, Doroudgar S, Glembotski CC (2017). ATF6 decreases myocardial ischemia/reperfusion damage and links ER stress and oxidative stress signaling pathways in the heart. Circ. Res., 120: 862-875. https://doi. org/10.1161/CIRCRESAHA.116.310266

- Kroeger H, Grimsey N, Paxman R, Chiang W, Plate L, Jones Y, Shaw PX, Trejo J, Tsang SH, Powers E, Kelly JW, Wiseman $\mathrm{RL}$, Lin JH (2018). The unfolded protein response regulator ATF6 promotes mesodermal differentiation. Sci. Signal, 11: 517. https://doi.org/10.1126/scisignal.aan5785

-Kropp J, Khatib H (2015). Characterization of microRNA in bovine in vitro culture media associated with embryo quality and development. J. Dairy Sci., 98: 6552-6563. https://doi. org/10.3168/jds.2015-9510

-Kropp J, Salih SM, Khatib H (2014). Expression of microRNAs in bovine and human pre-implantation embryo culture media. Front. Genet., 5: 91. https://doi.org/10.3389/ fgene.2014.00091

- Lanzarini F, Pereira FA, de Camargo J, Oliveira AM, Belaz KRA, Melendez-Perez JJ, Eberlin MN, Brum MCS, Mesquita FS, Sudano MJ (2021). ELOVL5 participates in embryonic lipid determination of cellular membranes and cytoplasmic droplets. Int. J. Mol. Sci., 22(1311): 1-16. https://doi.org/10.3390/ijms22031311

-Lasko P (2011). Posttranscriptional regulation in Drosophila oocytes and early embryos. Wiley Interdis. Rev., RNA2: 408-416. https://doi.org/10.1002/wrna.70

- Leme OL, Dufort I, Spricigo JFW, Braga TF, Sirard MA, Franco MM, Dode MAN (2016). Effect of vitrification using the cryotop method on the gene expression profile of in vitro produced bovine embryos. Theriogenol. Stoneham, 85(2): 724-733. https://doi.org/10.1016/j. theriogenology.2015.10.016

- Lima IMT, Souza AL (2009). Desenvolvimentoesobrevivência de embriões no período de préimplantação: Enfoqueemruminantes. Revista Brasileirade Reprodução Animal Belo Horizonte, 33(4): 194-202.

-Lin X, Beckers E, McCafferty S, Gansemans Y, SzymańskaKJ, PavaniKC, Catani JP, Nieuwerburgh FV, Deforce D, Sutter PD, Soom AV, Peelman L (2019). Bovine embryo-secreted microRNA-30c is a potential noninvasive biomarker for hampered preimplantation developmental competence. Front. Genet., 10: 315. https://doi.org/10.3389/ fgene.2019.00315

- Ling H, Fabbri M, Calin GA (2013). MicroRNAs and other noncoding RNAs as targets for anticancer drug development. Nat. Rev. Drug Discov., 12(11): 847-865. https://doi. org/10.1038/nrd4140

- Lodde V, Modina SC, Franciosi F, Zuccari E, Tessaro I, Luciano AM (2009). Localization of DNA methyltransferase-1 during oocyte differentiation, in vitro maturation and early embryonic development in cow. Eur. J. Histochem., 53(4): e24. https://doi.org/10.4081/ejh.2009.e24

- Lonergan P, Rizos D, Gutie'rrez-Ada'n A, Fair T, Boland MP (2003). Oocyte and embryo quality: effect of origin, culture conditions and gene expression patterns. Reprod. Dom. Anim., 38: 259-267. https://doi.org/10.1046/j.14390531.2003.00437.x

- Mahmoud KGhM, Scholkamy TH, Darwish SF (2015). Improvement of vitrification of in vitro produced buffalo embryos with a special reference to sex ratio following vitrification. Iran. J. Vet. Res., 16(4): 325-330.

- Marsico TV,De Camargo J, Roniele S, Valente, Mateus J, Sudano (2019). Embryo competence and cryosurvival: Molecular and cellular features. Anim. Reprod. 16(3): 423-439. https:// doi.org/10.21451/1984-3143-AR2019-0072

-McEvoy TG, Coull GD, Broadbent PJ, Hutchinson JS, Speake BK (2000). Fatty acid composition of lipids in immature cattle, pig and sheep oocytes with intact zonapellucida. J. Reprod. Fertil., 118: 163-170. https://doi.org/10.1530/ jrf.0.1180163

- Michalak M, Gye MC (2015). Endoplasmic reticulum stress in periimplantation embryos. Clin. Exp. Reprod. Med., 42(1): 1-7. https://doi.org/10.5653/cerm.2015.42.1.1

- Mondou E, Dufort I, Gohin M, Fournier E, Sirard MA (2012). Analysis of microRNAs and their precursors in bovine early embryonic development. Mol. Hum. Reprod., 18: 425- 434. https://doi.org/10.1093/molehr/gas015

- Nelson DL, Cox MM (2011). Princípios de bioquímica de Lehninger. 5. ed. Porto Alegre: Artmed., pp. 1304.

- Niwa K, Ohgoda O (1988). Synergistic effect of caffeine and heparin on in vitro fertilization of cattle oocytes matured in culture. Theriogenology, 30: 733-741. https://doi. org/10.1016/0093-691X(88)90308-1

- Paasch U, Sharma RK, Gupta AK, Grunewarld S, Mascha EJ, Thomas AJ, Glander HJ, AgarwalA (2004).Cryopreservation 
and thawing is associated with varying extent of activation of apoptotic machinery in subsets of ejaculated human spermatozoa. Biol. Reprod., 71(6): 1828-1837. https://doi. org/10.1095/biolreprod.103.025627

-Pero ME, Zullo G, Esposito L, AIannuzzi, Lombardi P, De Canditiis C, Neglia G, Gasparrini B (2018). Inhibition of apoptosis by caspase inhibitor Z-VAD-FMK improves cryotolerance of in vitro derived bovine embryos. Theriogenology, 108: 127-135. https://doi.org/10.1016/j. theriogenology.2017.11.031

- Ralston A, Rossant J (2008). Cdx2 acts downstream of cell polarization to cell autonomously promote trophectoderm fate in the early mouse embryo. Dev. Biol., 313: 614-629. https://doi.org/10.1016/j.ydbio.2007.10.054

- Reza AMM, Choi Y, Han SG, Song H, Park C, Hong K, JinHoi Kim J (2019). Roles of microRNAs in mammalian reproduction: from the commitment of germ cells to periimplantation embryos. Biol. Rev., 94: 415- 438. https://doi. org/10.1111/brv.12459

-Romek M, Gajda B, Krzysztofowicz E, Kepczynski M, Smorag Z (2011). Lipid content in pig blastocysts cultured in the presence or absence of protein and vitamin $\mathrm{E}$ or phenazineethosulfate. Folia Biol. (Krakow). 59: 45-52. https://doi.org/10.3409/fb59_1-2.45-52

- Rozen S, Skaletsky H (2000). Primer3 on the WWW for general users and for biologist programmers. Bioinf. Methods Protoc. Springer, pp. 365-386. https://doi.org/10.1385/159259-192-2:365

- Sadeesh EM, Sikka P, Balhara AK, Balhara S (2016). Developmental competence and expression profile of genes in buffalo (Bubalus bubalis) oocytes and embryos collected under different environmental stress. Cytotechnology, 68: 2271-2285. https://doi.org/10.1007/s10616-016-0022-y

-Salilew-Wondim D, Ahmad I, Gebremedhn S, Sahadevan S, Hossain MDM, Rings F, Hoelker M, Tholen E, Neuhoff C, Looft C, Schellander K, Tesfaye D (2014). The expression pattern of microRNAs in granulosa cells of subordinate and dominant follicles during the early luteal phase of the bovine estrous cycle. PLoS One, 9(9): e106795. https://doi. org/10.1371/journal.pone.0106795

-Salilew-Wondim D, Gebremedhn S, Hoelker M, Tholen E, Hailay T, Tesfaye DD (2020). The role of microRNAs in mammalian fertility: From gametogenesis to embryo implantation. Int. J. Mol. Sci. 21: 1-20. https://doi. org/10.3390/ijms21020585

- Sanches BV, Zangirolamo AF, da Silva NC, Morotti F, Seneda MM (2017). Cryopreservation of in vitro-produced embryos: Challenges for commercial implementation. Anim. Reprod., 14(3): 521-527. https://doi.org/10.21451/19843143-AR995

-Sandhu R, Rivenbark AG, Coleman WB (2012). Loss of posttranscriptional regulation of DNMT3b by microRNAs: A possible molecular mechanism for the hyper methylation defect observed in a subset of breast cancer cell lines. Int. J. Oncol., 41(2): 721-732. https://doi.org/10.3892/ ijo.2012.1505

- Seidel Jr. GE (2006). Modifying oocytes and embryos to improve their cryopreservation. Theriogenology, 65: 228235. https://doi.org/10.1016/j.theriogenology.2005.09.025

- Spricigo JFW, Morais K, Ferreira AR, Machado GM, Gomes AC, Rumpf R, Franco MM, Dode MA (2014). Vitrification of bovine oocytes at different meiotic stages using the cryotop method: Assessment of morphological, molecular and functional patterns. Cryobiol. San Diego, 69(2): 256265. https://doi.org/10.1016/j.cryobiol.2014.07.015

-Stroh C, Cassens U, Samraj AK, Sibrowski W, Schulze-Osthoff K, Los M (2002). The role of caspases in cryoinjury: caspase inhibition strongly improves the recovery of cryopreserved hematopoietic and other cells. Fed. Am. Soc. Exp. Biol., 16: 1651-1663. https://doi.org/10.1096/fj.02-0034fje

-Sudano MJ, Marinho LSR, Silveira JC, Basso AC, Bohrer R, Lamberti GSE, Watanabe YF, Seneda MM, Meirelles FV (2019). Evoluçãoaplicada da produção in vitro de embriõesbovinos. In: Gonçalves PBD, Figueiredo JR, Gasperin BG. (Ed.) Biotécnicasaplicadas à reprodução animal, 3 ed. Grupo Gen, in press.

-Sudano MJ, Paschoal DM, da Silva Rascado T, Magalhães LCO, Crocomo LF, de Lima-Neto JF, da Cruz LandimAlvarenga F (2011). Lipid content and apoptosis of in vitro produced bovine embryos as determinants of susceptibility to vitrification. Theriogenology, 75: 1211-1220. https://doi. org/10.1016/j.theriogenology.2010.11.033

- Sudano MJ, Rascado TD, Tata A, Belaz KR, Santos VG, Valente RS, Mesquita FS, Ferreira CR, Araujo JP, Eberlin MN, Landim-Alvarenga FD (2016). Lipidome signatures in early bovine embryo development. Theriogenology, 86: 472-484. https://doi.org/10.1016/j.theriogenology.2016.03.025

- Takahashi T, Inaba Y, Somfai T, Kaneda M, Geshi M, Nagai T, Manabe N (2013). Supplementation of culture medium with L-carnitine improves development and cryotolerance of bovine embryos produced in vitro. Reprod. Fertil. Dev., 25(4): 589-599. https://doi.org/10.1071/RD11262

-Tao YF, Qiang J, Bao J, Li H, Yin G, Xu P, Chen D (2018). miR205-5p negatively regulates hepatic acetyl-CoA carboxylase $\beta$ mRNA in lipid metabolism of Oreochromisniloticus. Gene, 660:1-7. https://doi.org/10.1016/j.gene.2018.03.064

-Tesfaye D, Gebremedhn S, Salilew-Wondim D, Hailay T, Hoelker M, Grosse-Brinkhaus C, Schellander K (2018). MicroRNAs: Tiny molecules with a significant role in mammalian follicular and oocyte development. Reproduction, 155: 121-135. https://doi.org/10.1530/ REP-17-0428

-Thompson JG (2000). In vitro culture and embryo metabolism of cattle and sheep embryos a decade of achievement. Anim. Reprod. Sci., 60-61: 263-275. https://doi.org/10.1016/ S0378-4320(00)00096-8

- Tsujii H, Khandoker MAMY, Hamano KI (2001). Lipid in mammalian embryo development. J. Mamm. Ova. Res., 18: 73-80. https://doi.org/10.1274/jmor.18.73

-Wei S, Shen X, Gong Z, Deng Y, Lai L, Liang H (2017). FSHR and LHR expression and signaling as well as maturation and apoptosis of cumulus oocyte complexes following treatment with FSH receptor binding inhibitor in sheep. Cell Physiol. Biochem., 43: 660-666. https://doi.org/10.1159/000480650

-Wu J, Ruas JL, Estall JL, Rasbach KA, Choi JH, Ye L, Bostrom P, Tyra HM, Crawford RW, Campbell KP, Rutkowski DT, Kaufman RJ, Spiegelman BM (2011). The unfolded protein response mediates adaptation to exercise in skeletal muscle through a PGC-1 $\alpha /$ ATF6 $\alpha$ complex. Cell Metab., 13: 160169. https://doi.org/10.1016/j.cmet.2011.01.003

-Xiao G, Xia C, Yang J, Liu J, Du H, Kang X, Lin Y, Guan R, Yan P, Tang S (2014). MiR-133b regulates the expression of the Actin protein TAGLN2 during oocyte growth and maturation: A potential target for infertility therapy. PLoS One, 9: e100751. https://doi.org/10.1371/journal. pone.0100751 
- Yu JW, Chen YS, Qin LM, Cheng LX, Ren GC, Cong PQ, Mo DL, He ZY (2014). Effect of miR-205 on 3T3-L1 preadipocyte differentiation through targeting to glycogen synthase kinase 3 beta. Biotechnol. Lett., 36(6): 1233-1243

https://doi.org/10.1007/s10529-014-1491-8 